\title{
PENGARUH INFLASI DAN BI 7 DAY REPO RATE TERHADAP NILAI AKTIVA BERSIH (NAB) REKSADANA SYARIAH DI INDONESIA PERIODE 2016-2020
}

\author{
Taufiq Ridwan Murtadho \\ Akuntansi, STIE Tri Dharma \\ taufiqridwan10@gmail.com
}

Ade Ponirah

Magister Ekonomi Syariah, UIN Sunan Gunung Djati Bandung

adeponirah@gmail.com

Wilashopa Nurdiani

Perbankan Syariah, Universitas Al Ma'soem

wilashopanurdiani13@gmail.com

\begin{abstract}
Abstrak
Nilai Aktiva Bersih (NAB) menjadi sorotan utama para investor karena menggambrkan total kekayaan bersih reksadana setiap harinya. Artikel ini bertujuan untuk menguji pengaruh Inflasi dan BI 7 Day Repo Rate terhadap Nilai Aktiva Bersih (NAB) Reksadana Syariah. Inflasi menunjukan kenaikan harga suatu komoditas secara keseluruhan dan berlangsung cukup lama atau berkelanjutan. Sedangkan BI 7 Day Repo Rate merupakan tingkat suku bunga dalam kebijakan moneter ditetapkan oleh bank Indonesia dan disampaikan pada publik. Metode dalam penelitian ini menggunakan metode deskriptif dan pendekatan kuantitatif, untuk mendeskripsikan hasil penelitian yang datanya disajikan dalam bentuk angka dengan menggunakan data sekunder dan didukung dengan studi kepustakaan serta dokumentasi, yang diolah secara statistik dan kuantitatif. Pada penelitian ini mendapatkan hasil bahwa secara parsial inflasi berpengaruh terhadap Nilai Aktiva Bersih dengan kontribusi pengaruh 61.1 persen, sedangkan BI 7 Day Repo Rate tidak berpengaruh terhadap Nilai Aktiva Bersih, dan secara simulta inflasi dan BI 7 Day Repo Rate berpengaruh terhadap nilai aktiva bersih sebesar 63.1 persen.
\end{abstract}

Kata Kunci : Inflasi, BI 7 Day Repo Rate, Nilai Aktiva Bersih, Reksadana Syariah

\begin{abstract}
Net Asset Value (NAV) is the main focus of investors because it describes the total net worth of mutual funds every day. This article aims to examine the effect of inflation and the BI 7 Day Repo Rate on the Net Asset Value (NAV) of Islamic Mutual Funds. Inflation shows an increase in the price of a commodity as a whole and lasts quite a long time or is sustainable. Meanwhile, the BI 7 Day Repo Rate is the interest rate in monetary policy set by Bank. Indonesia and presented to the public. The method in this study uses descriptive methods and quantitative approaches, to describe research results whose data is presented in the form of numbers using secondary data and is supported by literature studies and documentation, which are processed statistically and quantitatively. In this study, the results show that inflation partially affects Net Asset Value with a contribution of 61.1 percent, while the BI 7 Day Repo Rate has no effect on Net Asset Value, and simultaneously inflation and the BI 7 Day Repo Rate affect net asset value by 63.1 percent.
\end{abstract}

Keywords: Inflation, BI 7 Day Repo Rate, Net Asset Value, Islamic Mutual Funds 


\section{Pendahuluan}

Peningkatan industri keuangan konvensional diiringi juga dengan peningkatan industri keuangan syariah. Dalam menciptakan industri keuangan yang lebih stabil menjadi tantangan khusus. Hasil dari pencapaian ini terciptanya berbagai instrumen pasar modal dalam industri keuangan syariah. Maka menjadi stimulan investor untuk menginvestasikan dananya. Perkembangan ini dapat mengoptimalkan sumber daya yang ada dengan mengikuti pedoman syariah juga diiringi menjaga kestabilan kondisi internal perusahaan yaitu menjaga tingkat likuiditas dan tingkat keuntungan.

Berdasarkan aturan tertulis pihak yang mempunyai wewenang untuk mengawasi berjalannya pasar modal yaitu oleh Otoritas Jasa Keuangan (OJK). Pasar Modal berperan dalam pembangunan ekonomi negara dengan mengoptimalkan sarana investasi. Jika berkembang dengan baik dapat dijadikan sebagai tolak ukur kemajuan dari suatu negara (Purnomo, 2013). Pasar modal syariah hadir ditengah masyarakat Indonesia mayoritas muslim menjadi sarana investasi yang tepat karena sistem pasar modal ini terbebas dari unsur-unsur yang diharamkan seperti riba, maisir, gharar dan lain-lain (Widodo, 2015).

Reksadana syariah atau sering disebut dengan Islamic Mutual Fund satu diantaranya produk instrumen keuangan syariah yang saat ini sedang berkembang. Reksadana merupakan salah satu wadah untuk mengelola dana/modal dari dari pihak yang memiliki keinginan tinggi menginvestasikan dananya karena terkendala dalam waktu dan pengetahuan tak terbatas. Instrumen untuk berinvestasi dalam reksadana syariah diperbolehkan menempatkan pada instrumen yang sesuai dengan syariat Islam (Pipit, 2016). Dapat digunakan untuk mengukur kinerja investasi.

Nilai Aset Bersih (NAB) ialah banyaknya aset yang dikurangi dengan kewajiban. Dapat berfluktuatif setiap harinya tergantung kepada naik turunnya harga surat berharga. Ketika Terjadi peningkatan dapat digambarkan dengan peningkatan jumlah kepemilikan surat berharga (Usman, 2000). Berkaitan erat dengan nilai portofolio rekasadana masing-masing. Kekayaan ini berupa SBI, deposito, kas, saham, obligasi dan lainnya. Kewajibanya termasuk biaya manajer, biaya perantara, bank kustodian, pajak, serta surat berharga yang belum dilunasi (Sudaro, 2008).

Menurut Tandelilin faktor makro mempunyai peran secara empiris terhadap perkembangan investasi, termasuk tingkat pertumbuhan inflasi dan tingkat suku bunga (Tandelilin, 2010). Inflasi dapat didefiniskan sebagai peningkatan harga komoditas yang terus menerus secara keseluruhan. Jika kenaikan hanya pada komoditas tertentu saja dan tidak mewabah serta berkelanjutan tidak dapat dikatakan sebagai inflasi (Adrian \& Rachmawati, 2019). Kenaikan inflasi akan menurunkan laba perusahaan disebabkan oleh nilai barang maupun jasa yang beralih sehingga berakibat kepada proporsi bagi hasil yang dibagikan kepada investor, maka minat investor menurun karena tidak dapat memberikan retrun yang diharapkan. Dampak terbesar yaitu stock price mengikuti mengalami penurunan berdampak pula kepada nilai akrtiva bersih (Ilyas \& Shofawati, 2020).

Karl dan Fair berpendapat dalam "Ekonomi Moneter" suku bunga sebagai instrumen untuk membayar bunga pinjaman tahunan berupa presentase berdasarkan besarnya bunga yang diterima tiap tahun dibagi nominal pinjaman (Hasoloan, 2014). Umumnya definisi imbal hasil yang disediakan oleh bank kepada nasabah yang menyediakan atau menjual produknya berdasarkan prinsip konvensional (Kasmir, 2015). Jika BI 7 Day Repo Rate naik dengan diikuti pembayaran kembali atas pinjaman yang dikeluarkan oleh perusahaan berdampak pada penurunan imbal hasil yang dibagikan, tentunya nilai aktiva bersih akan mengalami penurunan (Karl \& Fair, 2001). 
Mengacu pada teori yang telah dipaparkan, maka dapat dirumuskan jika variabel yang diteliti mempunyai keterkaitan. Inflasi dan BI 7 Day Repo Rate dapat memberikan pengaruh terhadap Nilai Aktiva Bersih (NAB). Berikut data penelitain disajikan:

Tabel 1. Data Penelitian

\begin{tabular}{|c|c|c|c|c|}
\hline Peridoe & Triwulan & $\begin{array}{c}\text { Inflasi } \\
\mathbf{( \% )}\end{array}$ & $\begin{array}{c}\text { BI 7 Day Repo Rate } \\
\mathbf{( \% )}\end{array}$ & $\begin{array}{c}\text { NAB Reksadana Syariah } \\
\text { (Rp. Miliar) }\end{array}$ \\
\hline \multirow{4}{*}{2016} & I & 4.45 & 5.50 & 9.470 .14 \\
\cline { 2 - 5 } & II & 3.45 & 5.25 & 9.901 .24 \\
\cline { 2 - 5 } & III & 3.07 & 5.00 & 12.087 .00 \\
\cline { 2 - 5 } & IV & 3.02 & 4.75 & 14.914 .63 \\
\hline \multirow{4}{*}{2017} & I & 3.61 & 4.75 & 16.123 .54 \\
\cline { 2 - 5 } & II & 4.37 & 4.75 & 18.914 .54 \\
\cline { 2 - 5 } & III & 3.72 & 4.25 & 21.427 .72 \\
\cline { 2 - 5 } & IV & 3.61 & 4.25 & 28.311 .77 \\
\hline \multirow{4}{*}{2018} & I & 3.40 & 4.25 & 31.108 .82 \\
\cline { 2 - 5 } & II & 3.12 & 5.25 & 32.167 .28 \\
\cline { 2 - 5 } & III & 2.88 & 5.75 & 31.797 .51 \\
\cline { 2 - 5 } & IV & 3.13 & 6.00 & 34.491 .17 \\
\hline \multirow{4}{*}{2019} & I & 2.48 & 6.00 & 37.114 .19 \\
\cline { 2 - 5 } & II & 3.28 & 6.00 & 33.056 .75 \\
\cline { 2 - 5 } & III & 3.39 & 5.25 & 55.543 .29 \\
\cline { 2 - 5 } & IV & 2.72 & 5.00 & 53.735 .58 \\
\hline 2020 & I & 2.96 & 4.50 & 57.420 .96 \\
\cline { 2 - 5 } & II & 1.96 & 4.25 & 71.649 .52 \\
\cline { 2 - 5 } & III & 1.42 & 4.00 & 74.367 .44 \\
\cline { 2 - 5 } & IV & 1.68 & 3.75 & \\
\hline
\end{tabular}

Dari tabel di atas terdapat data yang fluktuatif disetiap triwulan, pada tahun 2016 mulai dari triwulan I hingga triwulan IV variabel independen terus menurun sedangkaan Nilai Aktiva Bersih (NAB) terus meningkat. Namun pada tahun 2017 mengalami fluktuatif Inflasi meningkat hanya pada triwulan II sedangkan BI 7 Day Repo Rate terus mengalami penurunan disetiap triuwlan berbeda dengan variabel terikat terus mengalami peningkatan. Menginjak tahun 2018 hampir semua variabel mengami peningkatan hanya pada triwulan III nilai Inflasi menurun. Tahun 2019 mulai dari triwulan I hingga triwulan IV Inflasi mengalami naik turun dengan didominasi penurunan terendah pada triwulan I, BI 7 Day Repo Rate terus mengalami penurunan hingga menginjak triwulan IV diikuti juga dengan nilai aktiva bersih yang berfluktuatif. Tahun terakhir 2020 tingkat Inflasi mengalami penurunan signifikan dibandingkan dengan tahun sebelumnya diikuti dengan BI 7 Day Rate Repo namun Nilai Aktiva Bersih (NAB) terus bertahan dengan peringkatnya. Berdasarkan data yang disajikan di atas menjadi landasan untuk dilakukannya penelitian dengan tujuan menguji dan menganalisis pengaruh dari inflasi dan BI 7 Day Rate Repo terhadap Nilai Aktiva Bersih Reksadana Syariah Indonesia.

\section{Metode}

Artikel ini diuji dengan metode deksriptif disertai pendekatan kuantitaif yang menguraikan secara terstruktur dari seluruh fakta serta hubungan antar variabel dengan menganalisis data yang berupa angka menggunakan uji statistik dengan menggunakan data sekunder. Metode perhitungan dengan menggunakan analisis regresi, pengujian hipotesis, dan pengujian kekuatan hubungan. Objek pada penelitian ini adalah data Nilai Aktiva Bersih Reksadana Syariah Indonesia yang diperoleh dari Otoritas Jasa Keuangan (OJK). 
Masing-masing variabel yang terdapat dalam penelitian ini dapat dilihat pada tabel operasionalisasi berikut ini

Tabel 2. Operasionalisasi Variabel Penelitian

\begin{tabular}{|c|c|c|c|c|}
\hline Tabel & Definisi & Indikator & Rumus & Skala \\
\hline Inflasi & $\begin{array}{l}\text { Kenaikan } \\
\text { harga secara } \\
\text { umum terus } \\
\text { menerus dari } \\
\text { suatu } \\
\text { perekonmian. }\end{array}$ & $\begin{array}{l}\text { Inflasi, } \\
\text { Indeks Harga } \\
\text { Konsumen } \\
\text { tahun dasar, } \\
\text { Indeks Harga } \\
\text { Konsumen }\end{array}$ & $=\frac{\mathrm{HKn}-\mathrm{HKn}-1}{H K n-1} \times 100 \%$ & Rasio \\
\hline $\begin{array}{l}\text { BI } 7 \text { Day } \\
\text { Repo Rate }\end{array}$ & $\begin{array}{l}\text { Pembayaran } \\
\text { bunga tahunan } \\
\text { dari suatu } \\
\text { pinjaman } \\
\text { berbentuk } \\
\text { presentase dari } \\
\text { pinjaman } \\
\text { diperoleh } \\
\text { berdasarkan } \\
\text { jumlah bunga } \\
\text { yang diterima } \\
\text { tiap tahun } \\
\text { dibagi dengan } \\
\text { jumlah } \\
\text { pinjaman. }\end{array}$ & - & - & Rasio \\
\hline $\begin{array}{l}\text { Nilai } \\
\text { Aktiva } \\
\text { Bersih }\end{array}$ & $\begin{array}{l}\text { Jumlah dana } \\
\text { yang dikelola } \\
\text { oleh pihak } \\
\text { manajer } \\
\text { investasi pada } \\
\text { suatu produk } \\
\text { reksadana. }\end{array}$ & $\begin{array}{l}\text { Total Aktiva } \\
\text { Bersih, } \\
\text { Jumlah Unit } \\
\text { Beredar }\end{array}$ & $=\frac{\text { Total Aktiva Bersih }}{\text { Jumlah Unit Beredar }} \times 100 \%$ & Rasio \\
\hline
\end{tabular}

\section{Hasil dan Pembahasan}

Hasil penelitian menunjukkan penjelasan terkait hasil penghitungan berupa uraian data dan pembahasan dari data-data penelitian tersebut. Hasil penelitian yang disajikan berupa hasil uji statistik dari analisis asumsi klasik, statistik deskriptif, dan analisis kuantitatif, keseluruhan data diolah menggunakan bantuan software Statistica Package For Social Science (SPSS).

\subsection{Uji Asumsi Klasik}

Uji asumsi klasik pada penelitian ini terdiri dari Uji Normalitas, Uji Multikolinearitas, dan Uji Heterokedastisitas. Berikut hasil perhitungan yang didapatkan dan interpretasinya:

\section{Uji Normalitas}

Uji normalitas merupakan uji asumsi klasik yang digunakan untuk melihat apakah data penelitian memiliki distribusi normal atau tidak. Uji ini dihitung menggunakan One sample 
Kolmogrov-Smirnov, Grafik Normal P-Plot, dan Gambar Histogram. Berikut hasil pengujian menggunakan yang pertama.

Tabel 3. Uji Normalitas One Sample Kolmogrov Smirnov Test One-Sample Kolmogorov-Smirnov Test

\begin{tabular}{|c|c|c|}
\hline & & Unstandardized Residual \\
\hline $\mathrm{N}$ & & 20 \\
\hline Normal Parameterca,b & Mean & $0 \mathrm{E}-7$ \\
\hline Nominal i aranteters, & Std. Deviation & 12311.41075150 \\
\hline & Absolute & .143 \\
\hline Most Extreme Differences & Positive & .114 \\
\hline & Negative & -.143 \\
\hline Kolmogorov-Smirnov Z & & .640 \\
\hline Asymp. Sig. (2-tailed) & & .808 \\
\hline
\end{tabular}

a. Test distribution is Normal.

b. Calculated from data.

Sumber: SPSS for windows versi 20.0

Mengacu pada tabel di atas, hasil yang diperoleh adalah data Inflasi, BI 7 Day Repo Rate, dan Nilai Aktiva Bersih Reksadana Syariah Indonesia berdistribusi normal karena hasil $0.808>$ 0.05. Hasil ini berimplikasi pada dapat dilakukannya analisis regresi. Selanjutnya untuk memperkuat hasil tabel di atas, uji normalitas dapat dilihat dari gambar di bawah ini:

Histogram

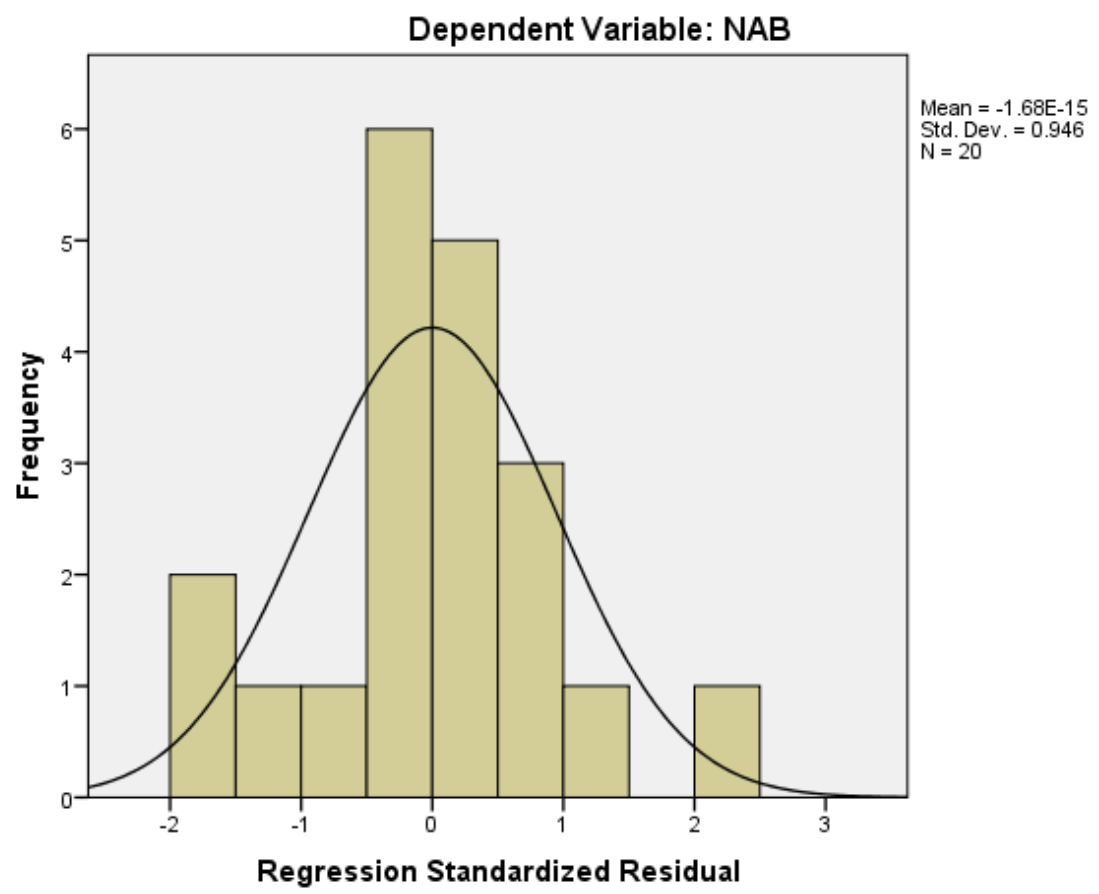

Gambar 1 Uji Normalitas Histogram

Sumber: SPSS for windows versi 20.0

Berdasarkan gambar histogram yang diperoleh, ditemukan hasil bahwa keseluruhan variabel dalam penelitian berdistribusi normal. Hal ini ditunjukkan dengan garis yang membentuk lonceng sempurna. Selanjutnya juga diperkuat dengan gambar berikut ini: 


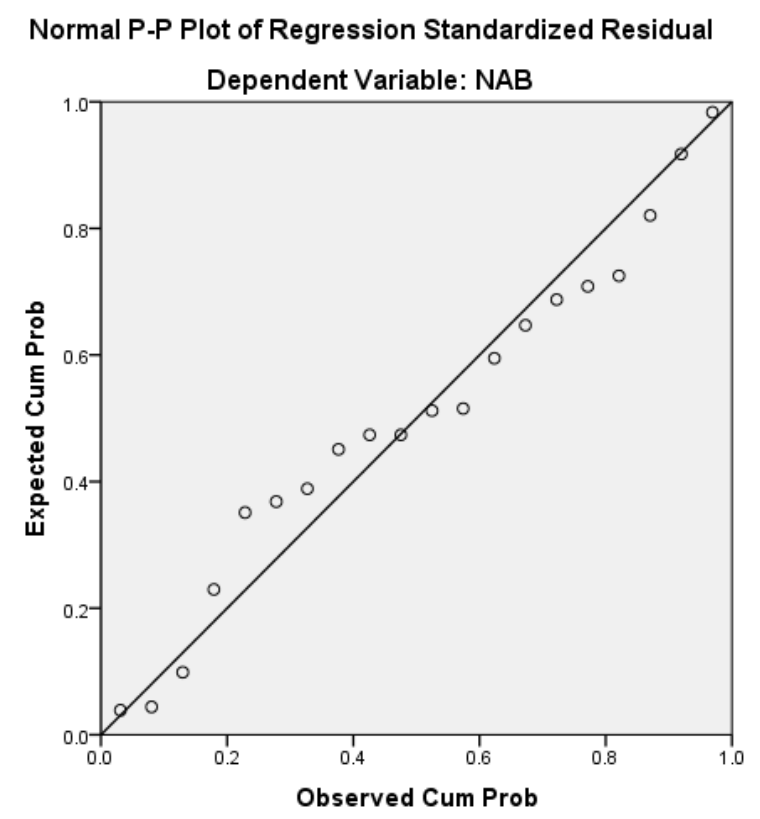

\section{Gambar 2 Uji Normalitas Normal P-Plot}

Sumber: SPSS for windows versi 20.0

Uji Normalitas menggunakan Normal P-Plot di atas membuktikan dan memperkuat dua hasil sebelumnya bahwa inflasi, BI 7 day rate repo, dan nilai aktiva bersih reksadana syariah Indonesia berdistribusi dengan normal. Hasil tersebut dapat dilihat dari titik yang tersebar disepanjang garis diagonal tersebut.

\section{Uji Multikolinearitas}

Uji multikolinearitas dilakukan untuk mengetahui tidak ada keterkaitan antar variabel bebas yang ada dalam penelitian, dalam hal ini Inflasi dan BI 7 Day Repo Rate. Model regresi yang baik tidak mengizinkan adanya hubungan antar variabel bebas, karena akan menimbulkan bias dan hasil diperoleh tidak optimal. Berikut hasil uji multikolinearitas yang pengambilan keputusannya menggunakan Tolerance $>0,1$ dan VIF $<10$.

\section{Tabel 4. Uji Multikolinearitas}

\section{Coefficients ${ }^{\mathrm{a}}$}

\begin{tabular}{|c|c|c|c|}
\hline \multirow{2}{*}{\multicolumn{2}{|c|}{ Model }} & \multicolumn{2}{|c|}{ Collinearity Statistics } \\
\hline & & Tolerance & VIF \\
\hline & Inflasi & .906 & 1.103 \\
\hline 1 & BI7DAYS & .906 & 1.103 \\
\hline
\end{tabular}

a. Dependent Variable: NAB

Sumber: SPSS for windows versi 20.0

Berdasarkan hasil perhitungan dari SPSS, diperoleh hasil bahwa tidak ada gejala multikolinearitas antara variabel inflasi dan BI 7 Day Repo Rate. Hasil ini diperoleh dengan pengambilan keputusan nilai VIF $1,103 \leq 10$ dan nilai tolerance $0.906 \geq 0.1$.

\section{Uji Heterokedastisitas}

Uji Heteroskedasitas bertujuan untuk menguji apakah dalam model regresi terjadi ketidaksamaan varian dengan pengamatan yang lain. Jika model regresi terdapat pola tertentu 
seperti titik-titik yang membentuk pola bergelombang atau melebar maka dapat disimpulkan adanya indikasi heteroskedastisitas.

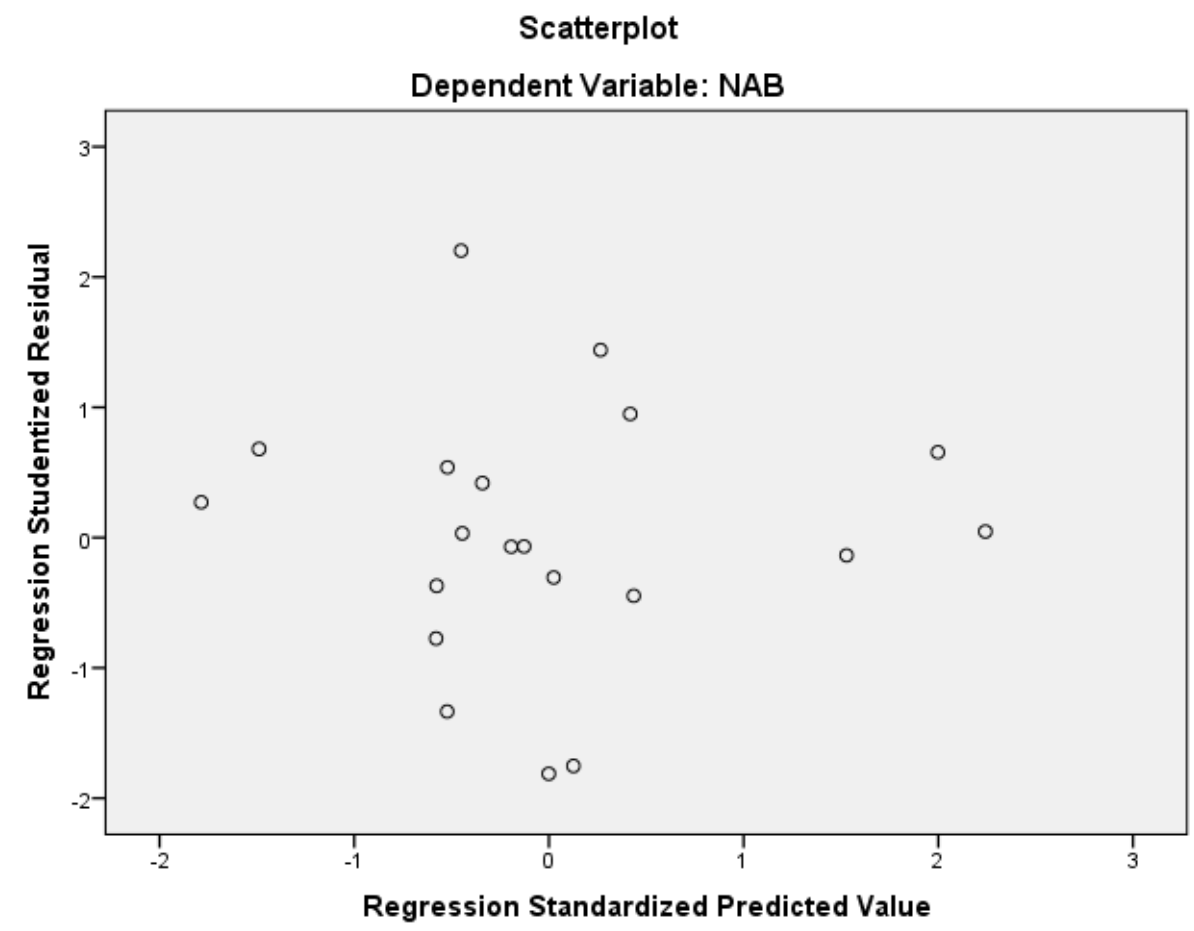

Gambar 3. Uji Heterokedastisitas Scatterplot

Sumber: SPSS for windows versi 20.0

Gambar di atas menunjukkan bahwa variabel dalam penelitian ini bebas dari gejala heterokedastisitas. Hasil ini dapat dilihat dari persebaran titik yang tidak membentuk suatu pola yang seragam, menyebar dengan baik. Dengan demikian pengujian selanjutnya dapat dilakukan.

\subsection{Statistik Deskriptif}

Statistik deskriptif digunakan untuk mendeskripsikan data penelitian yang terdiri dari jumlah data penelitian, nilai minimum data penelitian, nilai maksimum, nilai mean, dan standar deviasi pada penelitian. Hasil ini diperoleh melalui penghitungan statistik menggunakan SPSS. Berikut hasilnya:

Tabel 5. Statistik Deskriptif

Descriptive Statistics

\begin{tabular}{|l|r|r|r|r|r|}
\hline & $\mathrm{N}$ & Minimum & Maximum & \multicolumn{1}{c|}{ Mean } & Std. Deviation \\
\hline Inflasi & 20 & 1.42 & 4.45 & 3.0860 & .77490 \\
BI7DAYS & 20 & 3.75 & 6.00 & 4.9250 & .69348 \\
NAB & 20 & 9470.14 & 74367.44 & 35083.6070 & 20257.35691 \\
Valid N (listwise) & 20 & & & & \\
\hline
\end{tabular}

Sumber: SPSS for windows versi 20.0

Hasil statistik deskriptif menunjukkan masing-masing data pada variabel berjumlah 20 . Pada variabel inflasi nilai minimum adalah 1.42 persen, sedangkan nilai maksimum adalah 4.45 persen, nilai mean adalah 3.0860 persen dan standar deviasi 0.77490. Pada variabel BI 7 Day Repo Rate diperoleh nilai minimum 3.75 persen, nilai maksimum 6.00 persen, nilai mean 4.9250, dan nilai standar deviasi sebesar 0.69348. Terakhir variabel Nilai Aktiva Bersih (NAB) 
didapatkan nilai minimum sebesar 9470.14, nilai maksimum sebesar 74367.44, nilai mean sebesar 35083.6070, dan standar deviasi sebesar 20257.35691.

\subsection{Pengaruh Inflasi terhadap Nilai Aktiva Bersih (NAB) Reksadana Syariah Indonesia}

Inflasi dapat didefinisikan sebagai peningkatan harga sebuah komoditas yang bersifat menyeluruh serta berkelanjutan. Terdapat tiga syarat umum yang termasuk dalam kategori inflasi yaitu adanya peningkatan harga, peningkatan harga ini mencakup seluruh komoditas, dan berlangsung cukup lama (Rahardja, 2004). Kaum moneteris menganggap hal ini di akbiatkan oleh terlalu banyaknya jumlah uang yang beredar, sehngga daya beli tersebut menurun akibatnya harga barang-barang menjadi naik (Mangkoesoebroto, 1998).

Inflasi memiliki dampak positif atau negatif hal ini bergantung kepada tingkat keparahahnya. Beberapa ahli mengungkapkan lambatnya inflasi sebagai simulator pertumbuhan ekonomi. Jika Inflasi berada pada kategori ringan akan berdampak positif mendorong perekonomian lebih baik dengan adanya peningkatan pendapatan nasional, maka akan mendorong masyarakat untuk giat bekerja menghasilkan pendapatan yang tinggi. Hal ini menggambarkan juga kemampuan pihak emiten menghasilkan laba meningkat, karena biaya operasional perusahaan stabil tidak mengarah kepada kerugian (Sukirno, 2002).

Pada penelitian ini Inflasi memberikan dampak negatif dan memiliki pengaruh terhadap nilai aktiva bersih reksadana syariah Indonesia. Hasilnya dapat dilihat pada analisis regresi, hasil uji korelasi pearson product moment, uji koefisien determinasi, dan uji t. Hasil uji regresi linear sederhana menunjukkan hasil berikut ini:

Tabel 6. Analisis Regresi Inflasi terhadap NAB

Coefficients $^{\mathrm{a}}$

\begin{tabular}{|c|c|c|c|c|c|c|}
\hline \multirow{2}{*}{\multicolumn{2}{|c|}{ Model }} & \multicolumn{2}{|c|}{ Unstandardized Coefficients } & Standardized & \multirow[t]{2}{*}{$\mathrm{t}$} & \multirow[t]{2}{*}{ Sig. } \\
\hline & & B & Std. Error & Beta & & \\
\hline \multirow{2}{*}{1} & (Constant) & 98130.060 & 12213.842 & & 8.034 & .000 \\
\hline & Inflasi & -20429.829 & 3844.360 & -.781 & -5.314 & .000 \\
\hline
\end{tabular}

a. Dependent Variable: NAB

Sumber: SPSS for windows versi 20.0

Berdasarkan tabel di atas didapatkan persamaan regresi sederhana antara inflasi terhadap nilai aktiva bersih sebagai berikut:

$$
N B A=98130.060-20429.829 \text { Inflasi }
$$

Dari hasil perhitungan SPSS di atas, menjelaskan bahwa antara inflasi dengan nilai aktiva bersih menghasilkan nilai kontanta (a) sebesar $\mathbf{9 8 1 3 0 . 0 6 0}$ yang artinya apabila inflasi sama dengan nol (tidak ada perubahan) maka nilai aktiva bersih sebesar 98130.060. Nilai koefisien regresi (b) yang didapat sebesar -20429.829 artinya inflasi berpengaruh negatif terhadap nilai aktiva bersih. Nilai koefisien sebesar -20429.829 menunjukkan setiap kenaikan inflasi sebesar satu-satuan maka akan diikuti dengan penurunan nilai aktiva bersih sebesar -20429.829, begitu pula sebaliknya.

Selanjutnya kekuatan hubungan pengaruh inflasi terhadap nilai aktiva bersih dapat dilihat pada tabel berikut: 
Tabel 7. Analisis Korelasi PPM Inflasi terhadap NAB Correlations

\begin{tabular}{|rl|r|r|}
\hline & & Inflasi & \multicolumn{1}{|c|}{ NAB } \\
\hline \multirow{3}{*}{ Inflasi } & Pearson Correlation & 1 & $-.781^{* *}$ \\
& Sig. (2-tailed) & & .000 \\
& $\mathrm{~N}$ & 20 & 20 \\
$\mathrm{~N}$ & Pearson Correlation & $-.781^{* *}$ & 1 \\
& Sig. (2-tailed) & .000 & \\
& $\mathrm{~N}$ & 20 & 20 \\
\hline
\end{tabular}

**. Correlation is significant at the 0.01 level (2-tailed).

Sumber: SPSS for windows versi 20.0

Berdasarkan hasil perhitungan di atas, terdapat hubungan sebesar 0,781 antara inflasi terhadap nilai aktiva bersih, maka hasil perhitungan korelasi menunjukkan hubungan yang kuat, karena nilai tersebut berada pada kriteria interval 0,60 - 0,799. Jadi terdapat pengaruh yang kuat antara inflasi terhadap nilai aktiva bersih.

Selanjutnya kontribusi inflasi terhadap nilai aktiva bersih dapat dilihat pada tabel berikut ini:

Tabel 8. Analisis Koefisien Determinasi Inflasi terhadap NAB

Model Summary ${ }^{b}$

\begin{tabular}{|l|r|r|r|r|}
\hline Model & \multicolumn{1}{|c|}{$\mathrm{R}$} & \multicolumn{1}{c|}{ R Square } & Adjusted R Square & \multicolumn{1}{c|}{$\begin{array}{c}\text { Std. Error of the } \\
\text { Estimate }\end{array}$} \\
\hline 1 & $.781^{\mathrm{a}}$ & .611 & .589 & 12985.10895 \\
\hline
\end{tabular}

a. Predictors: (Constant), Inflasi

b. Dependent Variable: NAB

Sumber: SPSS for windows versi 20.0

Dari perhitungan tabel di atas menunjukkan $\mathrm{R}$ Square sebesar 0.611 atau $61.1 \%$ merupakan koefisien determinasi yang mengartikan bahwa nilai aktiva bersih secara parsial dipengaruhi oleh inflasi sebesar $61.1 \%$ sisanya sebesar $48.9 \%$ dipengaruhi oleh faktor lain di luar penelitian.

Terakhir untuk mengetahui pengaruh inflasi terhadap nilai aktiva bersih dapat diketahui melalui uji $t$ di bawah ini:

Tabel 9. Analisis Uji $t$ Inflasi terhadap NAB

Coefficients $^{\text {a }}$

\begin{tabular}{|rl|r|r|r|r|r|}
\hline \multirow{2}{*}{ Model } & \multicolumn{2}{|c|}{ Unstandardized Coefficients } & $\begin{array}{c}\text { Standardized } \\
\text { Coefficients }\end{array}$ & \multicolumn{1}{c|}{$\mathrm{t}$} & \multirow{2}{*}{ Sig. } \\
\cline { 3 - 7 } & \multicolumn{1}{|c|}{$\mathrm{B}$} & \multicolumn{1}{c|}{ Std. Error } & \multicolumn{1}{c|}{ Beta } & & \\
\hline \multirow{2}{*}{1} & (Constant) & 98130.060 & 12213.842 & & 8.034 & .000 \\
& Inflasi & -20429.829 & 3844.360 & -.781 & -5.314 & .000 \\
\hline
\end{tabular}

a. Dependent Variable: NAB

Sumber: SPSS for windows versi 20.0

Berdasarkan hasil SPSS for Windows V.20.0 di atas, diperoleh thitung sebesar 5.314 Sedangkan $t_{\text {tabel }}$ dengan $\mathrm{df}=20-2=18$ dengan tingkat signifikansi sebesar 5\% atau 0.05 , maka diperoleh tabel sebesar 1.694. Hal ini memenuhi syarat thitung $>$ tabel yakni $5.314>2.10092$ maka artinya inflasi berpengaruh signifikan terhadap nilai aktiva bersih reksadana syariah. 
Inflasi memiliki arah negatif terhadap Nilai Aset Bersih (NAB) mengartikan bahwa Inflasi akan menurunkan Nilai Aktiva Bersih (NAB). Implikasinya, inflasi akan merugikan semua kalangan termasuk emiten. Karena tingginya tingkat inflasi akan menyebabkan naiknya harga suatu komoditas, jika hal ini terjadi maka akan berimbas kepada penurunan pendapatan perusahaan karena harga pokok yang dikeluarkan meningkat namun daya beli konsumen menurun. Dengan menurunnya tingkat pendapatan perusahaan maka akan berdampak kepada menurunnya harga saham perusahaan tersebut. Sehingga investor akan memindahkan investasinya ke instrumen yang lain dengan risiko minim. Oleh karena itu reksadana mengalami penurunan pada nilai aktiva bersihnya akibat dari meningkatnya inflasi (Widodo, 2015).

Penelitian ini mendukung hasil penelitian yang dilakukan oleh Priyandini \& Wirman (2021), Shofia, Nurdin, \& Ibrahim (2018), dan Adrian \& Rachmawati dimana inflasi mempunyai pengaruh negatif dan signifikan pada NAB Reksadana Syariah. Namun penelitian ini juga bertolak belakang dengan penelitian dari Prasetyo \& Widiyanto (2019), Miha dan Nisful (2017), dan Imron (2015) temuan menunjukkan bahwa inflasi tidak berpengaruh terhadap nilai aktiva bersih reksadana syariah.

\subsection{Pengaruh BI 7 Day Repo Rate terhadap Nilai Aktiva Bersih (NAB) Reksadana Syariah Indonesia}

BI 7 Day Repo Rate ialah tingkat bunga menjadi patokan umumnya digunakan sebagai kebijakan moneter diumumkan kepada publik dan ditetapkan oleh bank Indonesia. Merupakan kebijakan baru yang bertujuan untuk meningkatkan pasar uang, perbankan maupun sektor riil. Tujuan pemerintah dalam kebijakan baru ini agar dapat memperkokoh kebijakan moneter pada pasar keuangan, peningkatan tranmisi kebijakan moneter diringi terciptanya pasar keuangan yang lebih dalam (Khoeruloh et al., 2020).

Ketika meningkat berdampak pada emiten harus mengurangi besarnya modal pinjaman agar pengembalian modal bunga tidak terlalu tinggi, jika hal ini terjadi maka menggambarkan kinerja perusahaan menurun berdampak kepada nilai pasar menurun akibatnya return yang akan dibagikan juga ikut menurun (Nandari, 2017).

Pada penelitian ini BI 7 Day Repo Rate memberikan dampak negatif dan memiliki pengaruh terhadap nilai aktiva bersih reksadana syariah Indonesia. Hasilnya dapat dilihat pada analisis regresi, hasil uji korelasi pearson product moment, uji koefisien determinasi, dan uji t. Hasil uji regresi linear sederhana menunjukkan hasil berikut ini:

Tabel 10. Analisis Regresi BI 7 Day Repo Rate terhadap NAB Coefficients $^{a}$

\begin{tabular}{|rc|r|r|r|r|r|}
\hline \multicolumn{2}{|l|}{ Model } & \multicolumn{2}{|c|}{ Unstandardized Coefficients } & $\begin{array}{c}\text { Standardized } \\
\text { Coefficients }\end{array}$ & \multicolumn{1}{c|}{$\mathrm{t}$} & \multirow{2}{*}{ Sig. } \\
\cline { 3 - 7 } & & \multicolumn{1}{|c|}{$\mathrm{B}$} & \multicolumn{1}{c|}{ Std. Error } & \multicolumn{1}{c|}{ Beta } & \\
\hline \multirow{2}{*}{1} & (Constant) & 88832.441 & 31748.438 & & 2.798 & .012 \\
& BI7DAYS & -10913.469 & 6386.516 & -.374 & -1.709 & .105 \\
\hline
\end{tabular}

a. Dependent Variable: NAB

Sumber: SPSS for windows versi 20.0

Berdasarkan tabel di atas didapatkan persamaan regresi sederhana antara BI 7 Day Repo Rate terhadap nilai aktiva bersih sebagai berikut:

$$
\boldsymbol{N B} \boldsymbol{A}=88832.441-10913.469 \text { BI } 7 \text { Day Repo Rate }
$$

Dari hasil perhitungan SPSS di atas, menjelaskan bahwa antara BI 7 Day Repo Rate dengan nilai aktiva bersih menghasilkan nilai kontanta (a) sebesar 88832.441 yang artinya apabila BI 7 
Day Repo Rate sama dengan nol (tidak ada perubahan) maka nilai aktiva bersih sebesar 88832.441. Nilai koefisien regresi (b) yang didapat sebesar -10913.469 artinya BI 7 Day Repo Rate berpengaruh negatif terhadap nilai aktiva bersih. Nilai koefisien sebesar -10913.469 menunjukkan setiap kenaikan BI 7 Day Repo Rate sebesar satu-satuan maka akan diikuti dengan penurunan nilai aktiva bersih sebesar -10913.469, begitu pula sebaliknya.

Selanjutnya kekuatan hubungan pengaruh BI 7 Day Repo Rate terhadap nilai aktiva bersih dapat dilihat pada tabel berikut:

\section{Tabel 11. Analisis Korelasi BI 7 Day Repo Rate terhadap NAB Correlations}

\begin{tabular}{|rl|r|r|}
\hline & & BI7DAYS & \multicolumn{1}{|c|}{ NAB } \\
\hline \multirow{3}{*}{ BI7DAYS } & Pearson Correlation & 1 & -.374 \\
& Sig. (2-tailed) & & .105 \\
& $\mathrm{~N}$ & 20 & 20 \\
$\mathrm{NAB}$ & Pearson Correlation & -.374 & 1 \\
& Sig. (2-tailed) & .105 & 20 \\
\hline
\end{tabular}

Sumber: SPSS for windows versi 20.0

Berdasarkan hasil perhitungan di atas, terdapat hubungan sebesar 0,374 antara BI 7 Day Repo Rate terhadap nilai aktiva bersih, maka hasil perhitungan korelasi menunjukkan hubungan yang kuat, karena nilai tersebut berada pada kriteria interval 0,30 - 0,499. Jadi terdapat pengaruh yang lemah antara BI 7 Day Repo Rate terhadap nilai aktiva bersih.

Selanjutnya kontribusi BI 7 Day Repo Rate terhadap nilai aktiva bersih dapat dilihat pada tabel berikut ini:

Tabel 12. Analisis Koefisien Determinasi BI 7 Day Repo Rate terhadap NAB Model Summary ${ }^{b}$

\begin{tabular}{|l|r|r|r|r|}
\hline Model & R & R Square & Adjusted R Square & $\begin{array}{c}\text { Std. Error of the } \\
\text { Estimate }\end{array}$ \\
\hline 1 & $.374 a$ & .140 & .092 & 19305.35140 \\
\hline
\end{tabular}

a. Predictors: (Constant), BI7DAYS

b. Dependent Variable: NAB

Sumber: SPSS for windows versi 20.0

Dari perhitungan tabel di atas menunjukkan $\mathrm{R}$ Square sebesar 0.140 atau $14.0 \%$ merupakan koefisien determinasi yang mengartikan bahwa nilai aktiva bersih secara parsial dipengaruhi oleh BI 7 Day Repo Rate sebesar 14\% sisanya sebesar 84\% dipengaruhi oleh faktor lain di luar penelitian.

Terakhir untuk mengetahui pengaruh BI 7 Day Repo Rate terhadap nilai aktiva bersih dapat diketahui melalui uji $t$ di bawah ini:

\section{Tabel 13. Uji $t$ BI 7 Day Repo Rate terhadap NAB Coefficients ${ }^{a}$}

\begin{tabular}{|rc|r|r|r|r|r|}
\hline \multicolumn{2}{|l|}{ Model } & \multicolumn{2}{|c|}{ Unstandardized Coefficients } & $\begin{array}{c}\text { Standardized } \\
\text { Coefficients }\end{array}$ & \multicolumn{1}{c|}{$\mathrm{t}$} & \multirow{2}{*}{ Sig. } \\
\cline { 3 - 6 } & \multicolumn{1}{|c|}{$\mathrm{B}$} & \multicolumn{1}{c|}{ Std. Error } & \multicolumn{1}{c|}{ Beta } & & \\
\hline \multirow{2}{*}{1} & (Constant) & 88832.441 & 31748.438 & & 2.798 & .012 \\
& BI7DAYS & -10913.469 & 6386.516 & -.374 & -1.709 & .105 \\
\hline
\end{tabular}

a. Dependent Variable: NAB

Sumber: SPSS for windows versi 20.0 
Berdasarkan hasil SPSS for Windows V.20.0 di atas, diperoleh thitung sebesar 1.709 Sedangkan tabel dengan $\mathrm{df}=20-2=18$ dengan tingkat signifikansi sebesar 5\% atau 0.05, maka diperoleh $t_{\text {tabel }}$ sebesar 1.694. Hal ini memenuhi syarat $t_{\text {hitung }}<t_{\text {tabel }}$ yakni $1.709<2.10092$ maka artinya BI 7 Day Repo Rate tidak berpengaruh terhadap nilai aktiva bersih reksadana syariah.

Saat suku bunga bank indonesia mengalami kenaikan, investor akan cenderung menginvestasikan dananya kepada sektor perbankan dalam bentuk tabungan atau deposito daripada membeli reksadana syariah. Walaupun risiko reksadana kecil, namun tetap saja mengandung risiko yang tidak dapat dipastikan saat suku bunga BI tinggi. Sedangkan jika disimpan dalam bentuk deposito dan tabungan maka jauh lebih aman dan dianggap memiliki tingkat pengembalian yang tinggi. Dan begitu pula sebaliknya jika suku bunga bank Indonesia turun maka akan berimbas pada permintaan yang tinggi pula pada sektor reksadana syariah karena return yang didapatkan akan jauh lebih tinggi dibandingkan hanya menyimpan uang di bank.

Implikasinya, BI 7 Day Repo Rate tidak memberikan pengaruh signifikan karena berbeda dengan reksadana konvensional. Reksadana syariah memiliki kebijakan investasi menggunakan instrumen investasi dengan portofolio yang berkategori bebas dari unsur haram dan diawasi langsung oleh Dewan Pengawa Syariah (DPS). Kategori halal ini yang terbebabas dari riba, maisyir, dan gharar. Sehingga sudah diketahui dengan jelas bahwa operasional reksadana syariah tidak menggunakan prinsip bunga. Maka jika BI 7 Day Repo Rate naik, kinerja perusahaan syariah akan tetap stabil begitupun juga dengan return akan tetap terkendali sehingga Nilai Aset Bersih (NAB) Reksadana Syariah juga mengikuti.

Penelitian ini bertolak belakang dengan hasil penelitian yang dilakukan oleh Pratiwi \& Budiman (2020) dan Ilyas \& Shofawati (2019) berdasarkan hasil pengujian, variabel BI 7 days repo rate memiliki pengaruh positif terhadap net asset value reksa dana saham syariah. namun sejalan dengan penelitian yang dilakukan oleh Hasil penelitian ini bertolak belakang dengan penelitian yang dilakukan oleh Azkiyah (2017) dan Utami \& Dharmastuti (2014) yang menyebutkan bahwa BI 7 days repo rate berpengaruh negatif terhadap NAB reksa dana jenis saham syariah.

\subsection{Pengaruh Inflasi dan BI 7 Day Repo Rate terhadap Nilai Aktiva Bersih (NAB) Reksadana Syariah Indonesia}

Naik turunnya investasi akan selalu ada kontribusi dari faktor lain. Secara teori faktor makro tersebut dapat mempengaruhi besarnya Nilai Aktiva Bersih (NAB) Reksadana Syariah sehingga diharapkan investor lebih memperhatikan dan menjadikan indikator untuk mengetahui Nilai Aktiva Bersih (NAB) per unit . Meningkatnya inflasi dapat menyebabkan menurunnya laba emiten syariah sehingga berdampak kepada nilai saham yang tercatat di pasar modal. Sehingga minat investor terhadap reksadana syariah berkurang maka dengan begitu Nilai Aktiva Bersih (NAB) menurun (Rachman \& Mawardi, 2015).

Analisis dalam penelitian ini tentunya menggunakan analisis regresi berganda. Berikut hasil pengujiannya:

Tabel 14. Hasil Uji Regresi Berganda Coefficients $^{a}$

\begin{tabular}{|rl|r|r|r|r|r|}
\hline \multicolumn{2}{|l|}{ Model } & \multicolumn{2}{|c|}{ Unstandardized Coefficients } & \multicolumn{1}{|c|}{$\begin{array}{c}\text { Standardized } \\
\text { Coefficients }\end{array}$} & \multicolumn{1}{c|}{$\mathrm{t}$} & \multirow{2}{*}{ Sig. } \\
\cline { 3 - 5 } & & \multicolumn{1}{|c|}{$\mathrm{B}$} & \multicolumn{1}{|c|}{ Std. Error } & \multicolumn{1}{c|}{ Beta } & & \\
\hline \multirow{2}{*}{1} & (Constant) & 115789.768 & 22142.836 & & 5.229 & .000 \\
& Inflasi & -19243.481 & 4047.795 & -.736 & -4.754 & .000 \\
& BI7DAYS & -4329.092 & 4522.997 & -.148 & -.957 & .352 \\
\hline
\end{tabular}

a. Dependent Variable: NAB

Sumber: SPSS for windows versi 20.0 
Dari hasil pengujian di atas yang menggunakan alat bantu yaitu SPSS, maka didapatkan model persamaan sebagai berikut:

$$
\mathrm{Y}=115789.768 \text { - 19243.481 Inflasi - 4329.092 BI } 7 \text { Day Repo Rate }
$$

Merujuk pada persamaan diatas, maka didapatkan nilai kontanta (a) sebesar 115789.768 mengandung arti jika nilai variabel independen berada pada posisi tetap maka akan berdampak kepada variabel dependen (Nilai Aktiva Bersih) berubah menjadi 115789.768.

Kemudian, untuk nilai koefisien $b_{1}$ sebesar-19243.481 nilai berarti bahwa jika Inflasi menurun sebanyak satu persen maka memberikan pengaruh terbalik kepada Nilai Aktiva Bersih (NAB) menjadi meningkat sebesar -19243.481. Selanjutnya, untuk variabel bebas kedua yaitu $B I$ 7 Day Repo Rate memiliki nilai koefisien $b_{1}$ sebesar -4329.092 menjelaskan jika BI 7 Day Repo Rate berubah sebesar sepersen maka akan memberikan dampak terbalik kepada Nilai Aktiva Bersih (NAB) meningkat sebesar -4329.092.

Untuk menunjukkan keeratan hubungan antara Inflasi dan BI 7 Day Repo Rate terhadap Nilai Aktiva Bersih (NAB), maka selanjutnya akan dianalisis dengan metode perhitungan statistik yaitu korelasi.

\section{Tabel 15. Analisis Korelasi dan Koefisien Determinasi}

Model Summary

\begin{tabular}{|l|r|r|r|r|}
\hline Model & \multicolumn{1}{|c|}{ R } & R Square & Adjusted R Square & \multicolumn{1}{c|}{$\begin{array}{c}\text { Std. Error of the } \\
\text { Estimate }\end{array}$} \\
\hline 1 & $.794^{\mathrm{a}}$ & .631 & .587 & 13015.47915 \\
\hline
\end{tabular}

a. Predictors: (Constant), BI7DAYS, Inflasi

Sumber: SPSS for windows versi 20.0

Berdasarkan hitungan SPSS versi 20 di atas maka nilai korelasi yaitu 0.794 yang berada pada interval 0.60 - 0.769 artinya Inflasi dan BI 7 Day Repo Rate memiliki hubungan kuat dengan Nilai Aktiva Bersih (NAB).

Mengacu pada hasil uji korelasi yang telah dilakukan sebelumnya, diketahui bahwa nilai $\mathrm{r}$ sebesar 0.794. Maka selanjutnya untuk mengetahui seberapa besar pengaruh Inflasi dan BI 7 Day Repo Rate terhadap Nilai Aktiva Bersih (NAB) dapat dilihat dari hasi R Square pada tabel 15 di atas. Hasil menunjukkan R Square 0,631, itu merupakan hasil koefisien determinasi dimana memiliki arti bahwa Inflasi dan BI 7 Day Repo Rate berkontribusi mempengaruhi fluktuasi Nilai Aktiva Bersih (NAB) sebesar 0,631 atau 63.1 persen, sedangkan sisanya 36.9 persen dipengaruhi oleh faktor lain.

Terakhir, untuk melihat pengaruh yang ditimbulkan oleh Inflasi dan BI 7 Day Repo Rate terhadap Nilai Aktiva Bersih (NAB) secara simultan, maka dianalisis menggunakan Uji F. Hasil uji F menunjukkan:

Tabel 16. Hasil Uji F

ANOVAa

\begin{tabular}{|rl|l|r|r|r|r|}
\hline Model & & Sum of Squares & df & Mean Square & F & Sig. \\
\hline \multirow{4}{*}{1} & Regression & 4917003810.954 & 2 & 2458501905.477 & 14.513 & $.000^{\mathrm{b}}$ \\
& Residual & 2879845859.152 & 17 & 169402697.597 & & \\
& Total & 7796849670.107 & 19 & & & \\
\hline
\end{tabular}

a. Dependent Variable: NAB

b. Predictors: (Constant), BI7DAYS, Inflasi

Sumber: SPSS for windows versi 20.0 
Mengacu pada hasil uji $f$ yang disajikan diatas, diperoleh hasil f-statistic sebesar 14,194 dengan signifikansi 0,000. Hasil ini mengandung arti bahwa Inflasi dan BI 7 Day Repo Rate dapat memberikan pengaruh signifikan terhadap Nilai Aktiva Bersih (NAB) Reksadana Syariah karena nilai signifikan lebih kecil dari 0,05 .

\section{Kesimpulan}

Berdasarkan pada penelitian dan pembahasan yang telah dipaparkan di atas, di dapatkan tiga kesimpulan akhir bahwa inflasi secara parsial berpengaruh terhadap Nilai Aset Bersih (NAB) Reksadana Syariah periode 2016-2020 dengan kontribusi pengaruh sebesar 61,1 persen dan korelasi yang kuat. Kemudian, BI 7 Day Repo Rate tidak berpengaruh terhadap Nilai Aset Bersih (NAB) Reksadana Syariah periode 2016-2020 dengan kontribusi pengaruh hanya 14 persen dan korelasi yang lemah. Dan terakhir secara simultan, Inflasi dan BI 7 Day Repo Rate dapat memberikan pengaruh signifikan terhadap Nilai Aktiva Bersih (NAB) Reksadana Syariah periode 2016-2020 dengan pengaruh yang kuat dan kontribusi sebesar 63.1 persen, sedangkan sisanya 36.9 persen dipengaruhi oleh faktor lain. Implikasi dalam penelitian ini adalah emiten harus tetap dapat mempertahankan Nilai Aktiva Bersih (NAB) dalam keadaan apapun, termasuk dengan adanya ketidakstabilan faktor makro yang berpotensi besar dapat mempengaruhi Nilai Aset Bersih (NAB) Reksadana Syariah. Meskipun reksadana syariah sistemnya berbeda halnya dengan reksadana konvensional yang tidak terlalu mengacu kepada tingkat suku bunga namun ada faktor makro lain yang kemungkinan besar dapat berdampak. Agar pekembangan reksadana syariah terus meningkat diharapkan pihak terkait dapat mensosialisasikan ke berbagai media, karena banyak orang yang ingin berinvestasi dengan sistem yang syariah namun terbatas oleh waktu dan pengetahuan, maka reksdana menjadi solusi yang tepat.

\section{Referensi}

Setiadi, N. J. (2013). Perilaku Konsumen. Jakarta: Kencana Prenada Media.

Adrian, M., \& Rachmawati, L. (2019). Pengaruh Inflasi Dan Nilai Tukar Rupiah terhadap Nilai Aktiva Bersih Reksadana Syariah. Jurnal Ekonomi Islam Volume 2 Nomor 1, 1-9.

Hidayat, M. (2010). Pengantar Ekonomi Syariah. Jakarta: Zikrul Media Intelektual.

Ilyas, M., \& Shofawati, A. (2019). PENGARUH INFLASI, NILAI TUKAR RUPIAH, BI RATE TERHADAP NILAI AKTIVA BERSIH REKSA DANA TERPROTEKSI SYARIAH PERIODE 2014-2018 DI INDONESIA. Jurnal Ekonomi Syariah Teori dan Terapan Vol. 6 No. 9, 1830-1839.

Kotler, P., \& Keller, K. L. (2007). Manajemen Pemasaran. Jakarta : PT. Indeks.

Maharani, N. K., \& Silvia, A. (2019). ANALISIS PENGARUH PENGETAHUAN DAN RELIGIUSITAS TERHADAP NIAT PEMBELIAN PRODUK KOSMETIK HALAL. AL-URBAN: Jurnal Ekonomi Syariah dan Filantropi Islam, Vol. 3, No. 1, 81-94.

Mulyati. (2019). Pengarub Tingkat Literasi Halal dan Tingkat Harga terbadap Keputusan Pembelian Produk. Makanan Impor (Studi pada Mahasiswa Jurusan Ekonomi Syariab UIN Sultan Maulana Hasanuddin Banten). UIN Sultan Maulana Hasanuddin: Banten.

Nasrullah, M. (2015). Islamic Branding, Religiusitas, dan Keputusan Konsumen Terhadap Produk. Jurnal Hukum Islam, Vol. 13, No. 2.

Prasetyo, D., \& Widiyanto. (2019). PENGARUH INFLASI, NILAI TUKAR RUPIAH, SUKU BUNGA BANK INDONESIA DAN HARGA EMAS TERHADAP NILAI AKTIVA 
BERSIH REKSADANASYARIAH. KONFERENSI ILMLAH MAHASISWA UNISSULA (KIMU) 2. Semarang: Universitas Islam Sultan Agung.

Pratiwi, I., \& Budiman, M. A. (2020). FAKTOR-FAKTOR MAKROEKONOMI YANG MEMENGARUHI NET ASSET VALUE REKSA DANA SAHAM SYARIAH DI INDONESIA . Jurnal Riset Terapan Akuntansi, Vol.4 No.2, 145-157.

Priyandini, S., \& Wirman. (2021). PENGARUH NILAI TUKAR (KURS) DAN INFLASI TERHADAP NILAI AKTIVA BERSIH REKSA DANA SYARIAH DI INDONESIA TAHUN 2015-2019. JIMEA | Jurnal Ilmiah MEA (Manajemen, Ekonomi, dan Akuntansi) Vol. 5 No. 1, 852-868.

Rachmanto, B. A., \& Widyanto, I. (2015). Pengaruh Pengetahuan Produk dan Norma Religius Terhadap Sikap Konsumen Dalam Niat Mengkonsumsi Produk Makanan dan Minuman Halal (Studi Kasus di Kota Semarang). Diponegoro Journal Of Management, 4(1), 280-211.

Rosida, R. (2018). Faktor-Faktor Yang Mempengaruhi Intensi Pembelian Kosmetik Halal (Survey Pada Muslimah Di Jawa Barat). Journal of Islamic Economics and Business.

Salehudin, I. (2010). Halal Literacy: A Concept Exploration and Measurement Validation. ASEAN Marketing Journal, 11 (1).

Shofia, G. K., Nurdin, \& Ibrahim, M. A. (2018). ANALISIS PENGARUH JAKARTA ISLAMIC INDEX (JII), NILAI TUKAR RUPIAH (KURS), DAN INFLASI TERHADAP NILAI AKTIVA BERSIH (NAB) REKSADANA SYARIAH CAMPURAN (PERIODE 2014-2016). Prosiding Hukum Ekonomi Syariah, Vol. 4. No. 2. Bandung: Universitas Islam Bandung.

Taufiq, A. R., \& Andina , E. M. (2018). Analisis Faktor-Faktor Pembentuk Konsumsi Status Pada Generasi Millennial. Jurnal Ekonomi Manajemen, 2 (4), 143-149.

Utami, M. L., \& Dharmastuti, C. F. (2014). Faktor Eksternal dan Internal yang Mempengaruhi Return Investasi Produk Reksa Dana Campuran di Indonesia. Media Ekonomi dan Manajemen, 29 (2), 97-110.

Vristiyana, V. M. (2019). PENGARUH RELIGIUSITAS DAN PENGETAHUAN PRODUK HALAL TERHADAP PENILAIAN PRODUK HALAL DAN MINAT PEMBELIAN PRODUK HALAL (Studi Kasus Pada Industri Makanan). EKOBIS Vol.20, No.1, 85-100.

Wicaksono, A. T., \& Astutik, T. P. (2020). LITERASI MAHASISWA PROGRAM STUDI TADRIS KIMIA TERHADAP UNDANG-UNDANG NO. 33 TAHUN 2014 TENTANG JAMINAN PRODUK. Ed-Humanistics. Volume 05 Nomor 01, 667-673.

Widodo, T. (2015). Pengarub Labelisasi Halal dan Harga terhadap Keputusan Pembelian Konsumen Pada Produk Indomie. Surakarta: Universitas Muhammadiyah Surakarta.

Zani, Rosidita, A. V., Panji, D., \& Massud, E. (2013). Analisis Pengarub Label Halal dan Aman Produk Pangan Terbadap Keputusan Pembelian Konsumen Di Malang. Malang: Universitas Brawijaya.

Zulham. (2016). Hukum Perlindungan Konsumen. Jakarta: Kencana. 